\title{
Cost of Providing Health Care Services in the Private Not for Profit Health Sector in Uganda: A Case Study of Nyenga Hospital (FY 2012/2013)
}

\author{
J. C. Okiria ${ }^{1}$, R. Kamara ${ }^{1}$ \\ ${ }^{1}$ International Health Sciences University-Kampala Uganda \\ Correspondence: Dr Okiria John Charles email; johncharlesokiria[at]yahoo.com or jokiria[at]ihsu.ac.ug
}

\begin{abstract}
This study determined the total cost, average cost and cost recovery of providing services in Nyenga Hospital. The total cost of providing the services for the financial year 2012/2013 was 451,484 USD with personnel cost being the highest cost driver at 220,109 USD. The average unit cost for the laboratory test was the lowest at 4,583 Ugx (1.8 USD), with the cost of CD4 counts and Viral loads tests excluded. As far as admissions are concerned the highest average cost was on Adult/Female and general ward at 207,532 Ugx (83 USD) and the lowest admission average unit cost was in paediatric ward at 87,626 Ugx (35.1 USD). The average unit cost of the HIV clinic was 251,083 Ugx (100.4 USD), this was the annual cost of managing a client per year without ARVs. In terms of cost recovery there were only surpluses in the OPD visits, minor operations and caesarean sections. (Bank of Uganda exchange rate was 1 dollar: 2,500 Uganda shillings).
\end{abstract}

Keywords: Total Cost, Step down Costing, Average Cost, Cost recovery, Allocation statistic

\section{Introduction}

Nyenga hospital is a 100 bed capacity Private Not for Profit (PNFP) Catholic Hospital owned by the Diocese of Lugazi. The Hospital employs a total of 103 staff (i.e. Professional and non-professional) working in the respective departments. Located on the Kampala - Jinja highway about $13 \mathrm{kms}$ to Jinja Town. Nyenga Hospital provides Preventive, Promotive, Curative and Supportive services through its various departments which include; the Out-Patients Department (OPD), In Patient Departments i.e. Maternity Ward with 14 beds, Children's Ward with 36 beds, Adult General Female 25 beds and Adult General Male 25 beds. Others include Operating Theatre, Eye Clinic, Skin Clinic, Laboratory and blood transfusion, Pharmacy, X-ray, Ultra Sound, Medical Records, PMCTC and VCT services, HII/AIDS Clinic and with an active PHC Department.

This study was to determine the cost of providing health services in Nyenga Hospital in the FY 2012/2013. The main objective of the study was to establish the cost of providing a unit output of a service in Nyenga hospital and the specific objectives were to; determine the total cost of providing services; determine the average cost per unit output and determine the average cost recovery per cost service charged in the FY 2012/13.

\section{Methodology}

\section{Study Design}

The study was a retrospective descriptive costs analysis study using a step down accounting methodology (Shepard 1998). The cost of providing health services in Nyenga in the financial year 2012/2013 was determined using relevant data from 1st July 2012 to 30th June 2013.
This period of study was chosen because Nyenga Hospital had already reported on the activities for this financial year and the data was likely to be available.

A step-down cost accounting method as described by Shepard and others in 1998 and by Conteh and Walker in (2004) was used (Shepard et al., 1998; Conteh and Walker, 2004).

\section{Scope of Study}

All the services provided in Nyenga hospital for the period of study were studied. These included; inpatient, outpatients, laboratory services, preventive, supportive and promotive services, excluding those not directly under the provision of health care services of the Hospital for example the training school and school health programs.

Buildings, equipment, drugs and other assets not used in the production of the services in the specified period of study were not costed as they were taken not to have been consumed.

Cost incurred during in service staff development were included in this costing study.

\section{Considerations}

Cost centers

Cost centers were taken as units of activity within the hospital that consume resources to produce or to contribute to the production of outputs and for which costs can be calculated. They were classified as overhead, intermediate and final cost centers. 


\section{International Journal of Science and Research (IJSR)}

ISSN (Online): 2319-7064

Index Copernicus Value (2013): 6.14 | Impact Factor (2015): 6.391

\section{Determination of Direct Costs per Cost Center}

\section{Personnel costs}

The actual salaries, all fringe benefits and allowances were considered and annualized.

The salaries and benefits of volunteers and expatriates were computed at the rate of hiring a local person for that post. The reason being that at times it might even be difficult to establish the true emoluments of these expatriates and they are not normally in line with the local salary rates and benefits. In addition, their rates are usually highly outrageous as compared to the local rates.

Salaries for Medical personnel who work in more than one department of the hospital were apportioned using the duty rosters present at each department. And where duty rosters were not available, time motion sheet were used to determine the proportions of time spent doing a particular activity and the salary apportioned accordingly.

\section{Medicines \& Sundries}

The total value of medicines $\&$ sundries was established from the total purchase invoices for the period of time under the study and costed directly to the wards and department on the basis of consumption. Assumption was made that all the drugs and sundries received during the financial year under study were consumed in the same period. The opening stocks and the closing stocks were considered in determining actual amount expended in the financial year under study.

\section{Buildings}

The hospital plans were used in the determination of the cost the cost of the buildings. However, in absence of the plan, the cost of the building was established by first measuring the square meter area and multiplied by the estimated present cost of constructing a square meter area and finally annualized at a given rate of (Buildings expected useful life $30 y e a r s$, at real interest rate of $3 \%$ ). This useful life span and rate was adopted as it has already been used in other cost studies. This enhances comparability of the findings (Flessa S, 1998; Guisti et al., 2004)

The shared buildings were apportioned according to the fraction of the space area under use by each or fraction of time. The cost per square meter was estimated at UGX.1,000,000/=(400 USD) for permanent buildings and the fence at $150,000 /=(60$ USD) per meter length (Ministry of Works Housing, Transport and Communication, and Nyenga Engineering Department estimates was adopted).For storeyed buildings, the cost of building the ground floor was taken to be the cost of each subsequent floors.

\section{Equipment, Furniture \& Motor Vehicles}

The inventory data was used to determine the types and the number of equipment in each cost center. The replacement value of equipments for each cost center was adduced from the asset records, average catalog prices of Joint Medical Stores, National Medical Stores and NACME where applicable.

These costs were the annualized to determine the value expended in one financial year. The heavy equipment like $\mathrm{X}$ - ray, Ultra Sound Scan, Operating tables, Dental chairs, Autoclaves, Drug cupboards and Furniture is hoped to have a useful life of 10 years and an interest rate of $3 \%$ was used. The motor vehicles and the light/portable equipment were considered to have a useful life span of 5 years and an interest real rate of $3 \%$ and were apportioned on the basis of usage if not specific to the cost centre. These useful life spans were adopted from other costing studies (Flessa S, 1998; Guisti et al., 2004)

For vehicles donated the current market value of replacement was used.

In calculating the annualization factor, a real interest rate of $3 \%$ was used in all related considerations as suggested by Shepard and others so as to ease comparison with other studies internationally (Shepard et. al, 1998).

\section{Maintenance of Medical and Non medical Equipment}

Costs of maintaining the equipment in the respective cost centers was determined from review of relevant records and interviews.

\section{Utilities}

These included electricity, water, and telephone. The costs were as per consumption.

\section{Results}

\section{Determination of Total Costs per Cost driver and Cost Centre}

This was done by first identifying the key cost drivers and the facility cost centers and outputs.

Table 1: Final cost centers, out puts for FY 2012/2013

\begin{tabular}{|c|c|c|c|c|}
\hline $\begin{array}{c}\text { Final Cost } \\
\text { Centre }\end{array}$ & Measure & Out put & Number & Death \\
\hline Laboratory & & Test & 19,452 & - \\
\hline Radiology. & Examination & Scan & & - \\
\hline \multirow[t]{3}{*}{ Theatre } & \multirow[t]{3}{*}{ Operation } & Minor & 931 & - \\
\hline & & Caesarean & 218 & - \\
\hline & & Major & 32 & - \\
\hline ANC clinic & & Visit & 4,055 & - \\
\hline \multirow[t]{2}{*}{$\begin{array}{l}\text { Pediatric } \\
\text { ward }\end{array}$} & \multirow[t]{2}{*}{ Inpatient } & $\begin{array}{l}\text { Inpatient } \\
\text { Day }\end{array}$ & 4,818 & \multirow[t]{2}{*}{44} \\
\hline & & Admission & 1,394 & \\
\hline \multirow[t]{2}{*}{$\begin{array}{l}\text { Maternity } \\
\text { ward }\end{array}$} & \multirow[t]{2}{*}{ Inpatient } & $\begin{array}{c}\text { Inpatient } \\
\text { Day }\end{array}$ & 3,404 & \multirow[t]{2}{*}{3} \\
\hline & & Admission & 859 & \\
\hline \multirow[t]{2}{*}{ Female ward } & \multirow[t]{2}{*}{ Inpatient } & $\begin{array}{c}\text { Inpatient } \\
\text { Day }\end{array}$ & 2,442 & \multirow[t]{2}{*}{18} \\
\hline & & Admission & 706 & \\
\hline \multirow[t]{2}{*}{ Male } & \multirow[t]{2}{*}{ Inpatient } & $\begin{array}{c}\text { Inpatient } \\
\text { Day }\end{array}$ & 1,589 & \multirow[t]{2}{*}{31} \\
\hline & & Admission & 422 & \\
\hline OPD & Attendance & Visit & 19,692 & - \\
\hline HIV clinic & Client & Client & 1,228 & - \\
\hline
\end{tabular}

\section{Source: HMIS 105/108}

According to the HMIS 105 and 108 reports there were a total of 19,452 lab tests excluding CD4 and Viral load test carried out, with the OPD utilization of 19,692 visits. The

\section{Volume 5 Issue 6, June 2016 www.ijsr.net}




\section{International Journal of Science and Research (IJSR) \\ ISSN (Online): 2319-7064}

Index Copernicus Value (2013): 6.14 | Impact Factor (2015): 6.391

highest inpatient admissions were 1,394 in paediatric ward in the FY 2012/2013. There were 1.228 active HIV/AIDS clients on first line, second line and pre ART as shown in table 1 above.

Table 2: Summary of Direct Cost per Cost Centre and Cost Driver

\begin{tabular}{|c|c|c|c|c|c|c|c|}
\hline Cost Centre & Personnel & $\begin{array}{c}\text { Drugs/sundries/ } \\
\text { reagents }\end{array}$ & $\begin{array}{c}\text { Admin. \& } \\
\text { Maintenance }\end{array}$ & Buildings & $\begin{array}{c}\text { Medical \& Non } \\
\text { Medical Equipments }\end{array}$ & Total & $U S D$ \\
\hline \multicolumn{8}{|c|}{ Overhead Cost Centre } \\
\hline Administration & $119,172,000$ & - & $270,160,911$ & $16,159,184$ & $5,615,475$ & $411,107,569$ & 164,443 \\
\hline Transport. & $6,600,000$ & - & - & - & $27,510,917$ & $34,110,917$ & 13,644 \\
\hline Security. & $19,476,000$ & - & - & - & 11,137 & $19,487,137$ & 7,795 \\
\hline \multicolumn{8}{|c|}{ Ancillary Cost Centre } \\
\hline Stores & $1,596,000$ & - & - & $2,489,796$ & 121,923 & $4,207,719$ & 1,683 \\
\hline Pharmacy & $12,360,000$ & - & - & $4,668,367$ & 341,149 & $17,369,516$ & 6,948 \\
\hline Mortuary. & $2,760,000$ & 187,420 & - & $2,040,816$ & - & $4,988,236$ & 1,995 \\
\hline Laundry & $2,760,000$ & 897,700 & - & $8,326,531$ & 3,517 & $11,987,748$ & 4,795 \\
\hline $\begin{array}{l}\text { Final Cost } \\
\text { Centre }\end{array}$ & - & & & - & - & - & \\
\hline Laboratory & $13,017,600$ & $24,631,377$ & - & $4,310,204$ & $4,990,504$ & $46,949,685$ & 18,780 \\
\hline Radiology. & $1,495,200$ & 792,885 & - & $1,697,959$ & 790,739 & $4,776,783$ & 1,911 \\
\hline Theatre & $25,726,140$ & $7,135,966$ & - & $10,640,306$ & $2,150,059$ & $45,652,471$ & 18,261 \\
\hline $\begin{array}{l}\mathrm{MCH} / \mathrm{ANC} \\
\text { clinic }\end{array}$ & $11,904,000$ & $4,757,311$ & - & $5,334,184$ & 767,878 & $22,763,373$ & 9,105 \\
\hline Pediatric ward & $35,354,760$ & $13,064,818$ & - & $12,526,531$ & $1,210,434$ & $62,156,542$ & 24,863 \\
\hline Maternity ward & $37,922,760$ & $10,307,507$ & - & $24,244,898$ & $3,294,842$ & $75,770,007$ & 30,308 \\
\hline $\begin{array}{c}\text { Adult and } \\
\text { General Ward }\end{array}$ & $41,880,636$ & $19,029,244$ & - & $15,153,061$ & $2,562,720$ & $78,625,661$ & 31,450 \\
\hline OPD & $35,736,180$ & $11,271,933$ & - & $10,255,102$ & $1,024,033$ & $58,287,248$ & 23,315 \\
\hline Male ward & $22,116,272$ & $5,000,678$ & - & $12,526,531$ & 1,295 & $39,644,776$ & 15,858 \\
\hline HIV clinic & $154,874,400$ & $6,550,196$ & - & $19,917,347$ & - & $181,341,943$ & 72,537 \\
\hline Cervical cancer & $5,520,000$ & 240,890 & - & $2,155,102$ & $1,565,651$ & $9,481,643$ & 3,793 \\
\hline Total & $550,271,948$ & $103,867,925$ & $270,160,911$ & $152,445,919$ & $51,962,273$ & $1,128,708,974$ & 451,484 \\
\hline USD & 220,109 & 41,547 & 108,064 & 60,978 & 20,785 & 451,484 & \\
\hline
\end{tabular}

As shown in table 2 the total costs expended by the hospital in the FY 2012/2013 was 1,128,708,974 Ugx (451,483 US dollars) with the highest being from the human resources with 550,271,948 Ugx (220,108 US dollars) and the lowest from medical and non medical equipment at 51,962,271 $\mathrm{Ugx}$ (20,784 US dollars).

\section{Determination of the Average Unit Costs}

Two scenarios were considered namely the average unit cost under total cost and under recurrent expenditure only.

\section{Scenario One: Average Unit Cost under Total Cost}

Table 3: Average Unit Cost with total cost considered

\begin{tabular}{|c|c|c|c|}
\hline Final Cost Centre & $\begin{array}{c}\text { Total Cost per } \\
\text { Cost Centre in } \\
\text { USD }\end{array}$ & $\begin{array}{c}\text { Unit of } \\
\text { Measure }\end{array}$ & $\begin{array}{c}\text { Average } \\
\text { Unit cost } \\
\text { in USD }\end{array}$ \\
\hline Laboratory & 35,658 & Test & 1.8 \\
\hline OPD & 67,256 & Visit & 3.4 \\
\hline MCH/ANC & 23,883 & Visit & 5.9 \\
\hline Radiology. & 4,403 & Scan & 14.9 \\
\hline & \multirow{2}{*}{38,003} & Major & 718 \\
\cline { 3 - 4 } & & Cesarean & 52.7 \\
\cline { 3 - 4 } Theatre & 48,860 & Minor & 3.8 \\
\hline Pediatric ward & 54,997 & Admission & 35.1 \\
\hline Maternity ward & 29,743 & Admission & 64 \\
\hline Male ward & 58,607 & Admission & 70.5 \\
\hline $\begin{array}{c}\text { Female and } \\
\text { General Ward }\end{array}$ & 123,332 & Visit & 100.4 \\
\hline HIV clinic & & \multicolumn{2}{|c}{} \\
\hline \multicolumn{2}{|c|}{}
\end{tabular}

As shown in the table 3 , the average unit cost for the laboratory test was the lowest at $4,583 \mathrm{Ugx}$ (1.8 USD). However, this cost excludes the cost of CD4 counts and Viral loads tests. As far as admissions are concerned the highest average cost was on Adult/Female and general ward at 207,532 Ugx (83 USD) and the lowest admission average unit cost was in paediatric ward at 87,626 Ugx (35.1 USD). The average unit cost of the HIV clinic of 251,083 Ugx (100.4 USD), is of annual cost of managing a client per year without ARVs.

Table 4: Average cost per type of operation

\begin{tabular}{|c|c|c|c|c|}
\hline \multirow{2}{*}{ Operation } & \multirow{2}{*}{$\begin{array}{c}\text { Total Cost } \\
\text { per type of } \\
\text { operation }\end{array}$} & $\begin{array}{c}\text { Unit } \\
\text { Out } \\
\text { puts }\end{array}$ & Ugx & USD \\
\cline { 4 - 5 } & $57,452,945$ & 32 & $1,795,405$ & 718 \\
\hline $\begin{array}{c}\text { Major } \\
\text { Operations }\end{array}$ & $52,726,473$ & 218 & 131,773 & 53 \\
\hline $\begin{array}{c}\text { Caesarian } \\
\text { Section }\end{array}$ & 28,78 Unit Cost \\
\hline $\begin{array}{c}\text { Minor } \\
\text { Operations }\end{array}$ & $8,828,874$ & 931 & 9,483 & 4 \\
\hline $\begin{array}{c}\text { Total } \\
\text { /Average }\end{array}$ & $\mathbf{9 5 , 0 0 8 , 2 9 2}$ & $\mathbf{1 1 8 1}$ & $\mathbf{8 0 , 4 4 7}$ & 32 \\
\hline
\end{tabular}

From the practical aspects of the operations in theatre three categories of operations are reported as Major, Caesarean and the Minors. Each of this has different requirements in terms of tome and human resources. So it will be wrong to just get the average cost of an operation without considering the major differences that they demand. The redistribution of theatre costs is shown in table 9. Because of the few major operations done the average cost is as high as 1,795,405 $\mathrm{Ugx}$ (718 USD). This was because only 32 major operations were

\section{Volume 5 Issue 6, June 2016} www.ijsr.net

Licensed Under Creative Commons Attribution CC BY 


\section{International Journal of Science and Research (IJSR) \\ ISSN (Online): 2319-7064 \\ Index Copernicus Value (2013): 6.14 | Impact Factor (2015): 6.391}

reported to have been done in the whole year, however just an increase of one major operation per day would reduce the unit cost by more than ten times. The average cost of the minor operations which were mainly safe male circumcision was 9,483 Ugx (3.8USD). See table 4 above.

Table 5: Average Unit cost per Inpatient day with total cost scenario

\begin{tabular}{|c|c|c|c|}
\hline \multirow{2}{*}{ Cost Centre } & \multirow{2}{*}{$\begin{array}{c}\text { Total Cost in } \\
\text { USD }\end{array}$} & \multirow{2}{*}{$\begin{array}{c}\text { Inpatien } \\
\text { t Days }\end{array}$} & $\begin{array}{c}\text { Average } \\
\text { Unit Cost }\end{array}$ \\
\cline { 4 - 4 } & 48,860 & 4,818 & USD \\
\hline Pediatric ward & 54,997 & 3,404 & 10.1 \\
\hline Maternity ward & 29,743 & 1,589 & 18.7 \\
\hline Male ward & 58,607 & 2,442 & 24 \\
\hline $\begin{array}{c}\text { Female and General } \\
\text { Ward }\end{array}$ & $\mathbf{1 9 2 , 2 0 7}$ & $\mathbf{1 2 , 2 5 3}$ & $\mathbf{1 5 . 7}$ \\
\hline $\begin{array}{c}\text { TOTAL } \\
\text { /AVERAGE }\end{array}$ & \multicolumn{2}{|c}{} \\
\hline
\end{tabular}

On average the average cost of an inpatient day in the hospital was 39,216 Ugx (15.7 USD). Female and general ward had the highest average unit cost of 59,999 Ugx (24 USD) per inpatient day with paediatric ward having the lowest at 25,353 Ugx (10.1 USD).

\section{Scenario Two: Average Unit Cost with Re Current Expenditures Only}

In this scenario only the costs of human resources, medicines and sundries, maintenance and utilities were considered. The cost of infrastructure and medical equipments were excluded

The highest average cost was still the major operation at $1,307,997 \operatorname{Ugx}(523.2$ USD). Overall there is a minimal reduction of the costs across the cost centres and unit out puts with highest being in the radiology cost centre of about $30 \%$. (Table 6).

Table 6: Average Unit cost with recurrent expenditure only

\begin{tabular}{|c|c|c|c|}
\hline Cost centre & $\begin{array}{c}\text { Recurrent } \\
\text { Cost in USD }\end{array}$ & $\begin{array}{c}\text { Unit of } \\
\text { Measure }\end{array}$ & $\begin{array}{c}\text { Average } \\
\text { cost in } \\
\text { USD }\end{array}$ \\
\hline Laboratory & 30,000 & Test & 1.5 \\
\hline OPD & 56,538 & Visit & 2.9 \\
\hline MCH/ANC clinic & 18,679 & Visit & 4.6 \\
\hline Radiology & 3,005 & Scan & 10.2 \\
\hline \multirow{2}{*}{ Theatre } & 3,532 & Minor & 3.8 \\
\cline { 2 - 4 } & 11,491 & Cesarean & 52.7 \\
\hline Pediatric ward & 36,742 & Major & 523.2 \\
\hline Maternity ward & 37,307 & Admission & 28.4 \\
\hline Male ward & 21,879 & Admission & 43.4 \\
\hline Adult and General & 47,431 & Admission & 67.2 \\
\hline Ward & 115,966 & Visit & 94.4 \\
\hline HIV clinic & & & \\
\hline
\end{tabular}

Table 8: Proportion of the recurrent costs on average unit cost of inpatient day

\begin{tabular}{|c|c|c|c|}
\hline Cost centre & \multicolumn{2}{|c|}{ Average Unit Cost } & \multicolumn{2}{|c|}{$\begin{array}{c}\text { Percentage } \\
\text { contribution of the } \\
\text { recurrent costs }\end{array}$} \\
\hline & Recurrent & $\begin{array}{c}\text { Total } \\
\text { cost }\end{array}$ & \\
\hline Pediatric ward & 20,531 & 25,353 & 81.0 \\
\hline Maternity ward & 27,399 & 40,392 & 67.8 \\
\hline Male ward & 34,422 & 46,795 & 73.6 \\
\hline $\begin{array}{c}\text { Adult and } \\
\text { General Ward }\end{array}$ & 48,557 & 59,999 & 80.9 \\
\hline $\begin{array}{c}\text { Overall average } \\
\text { Mval }\end{array}$ & 29,826 & 39,216 & 76.1 \\
\hline
\end{tabular}

On average over $76 \%$ costs that are incurred in the provision of the services in the facility are contributed by the recurrent costs. The over cost of an inpatient day was majorly due to 


\section{International Journal of Science and Research (IJSR) \\ ISSN (Online): 2319-7064}

Index Copernicus Value (2013): 6.14 | Impact Factor (2015): 6.391

the medicines, the human resources and maintenance. (Table 8)

\section{Objective Three: Determination of Costs Recovered / Lost}

Table 9: Percentage cost recovery under total cost scenario

\begin{tabular}{|c|c|c|c|c|}
\hline Cost Centre & $\begin{array}{c}\text { Unit } \\
\text { Measure }\end{array}$ & Cost & $\begin{array}{c}\text { Price/ } \\
\text { Charge }\end{array}$ & $\begin{array}{c}\text { Percentage } \\
\text { Recovery }\end{array}$ \\
\hline Laboratory & Test & 4,583 & 3,900 & -15 \\
\hline OPD & Visit & 8,538 & 9,500 & 11 \\
\hline MCH/ANC & Visit & 14,725 & 3,000 & -80 \\
\hline Radiology & Scan & 37,186 & 20,000 & -46 \\
\hline \multirow{2}{*}{ Theatre } & Minor & 9,483 & 21,500 & 127 \\
\cline { 2 - 5 } & Cesarean & 131,773 & 180,000 & 37 \\
\cline { 2 - 5 } & Major & $\begin{array}{c}1,795,40 \\
5\end{array}$ & 170,000 & -91 \\
\hline Pediatric ward & Admission & 87,626 & 30,000 & -66 \\
\hline $\begin{array}{c}\text { Maternity } \\
\text { ward }\end{array}$ & Admission & 160,061 & 55,000 & -66 \\
\hline Male ward & Admission & 176,202 & 55,000 & -69 \\
\hline $\begin{array}{c}\text { Adult and } \\
\text { General Ward }\end{array}$ & Admission & 207,532 & 55,000 & -73 \\
\hline HIV clinic & Visit & 251,083 & 0 & -100 \\
\hline
\end{tabular}

The average charges/prices are charged to patients in the hospital was used to determine the level of cost recovery in the two scenarios.

Under the total cost scenario there were only surpluses in the OPD visit of only $963 \mathrm{Ugx}$ (0.4 USD) per visit on average, $12,012 \mathrm{Ugx}$ (4.8 USD) on minor operations and 48,227Ugx (19.3 USD) on average on caesarean sections. Otherwise all the rest were on a deficit at different rates/ percentages.

Table 10: Percentage cost recovery/loss under recurrent expenditure scenario

\begin{tabular}{|c|c|c|c|c|}
\hline Cost Centre & $\begin{array}{c}\text { Unit } \\
\text { Measure }\end{array}$ & Cost & $\begin{array}{c}\text { Price/ } \\
\text { Charge }\end{array}$ & $\begin{array}{c}\text { Percentage } \\
\text { Recovery }\end{array}$ \\
\hline Laboratory & Test & 3,856 & 3,900 & 1.2 \\
\hline OPD & Visit & 7,178 & 9,500 & 32.4 \\
\hline CH/ANC & Visit & 11,516 & 3,000 & -73.9 \\
\hline Radiology & Scan & 25,386 & 20,000 & -21.2 \\
\hline \multirow{2}{*}{ Theatre } & Minor & 6,909 & 21,500 & 211.2 \\
\cline { 2 - 5 } & Cesarean & 96,000 & 180,000 & 87.5 \\
\cline { 2 - 5 } & Major & $1,307,997$ & 170,000 & -87.0 \\
\hline $\begin{array}{c}\text { Pediatric } \\
\text { ward }\end{array}$ & Admission & 70,961 & 30,000 & -57.7 \\
\hline $\begin{array}{c}\text { Maternity } \\
\text { ward }\end{array}$ & Admission & 108,577 & 55,000 & -49.3 \\
\hline Male ward & Admission & 129,615 & 55,000 & -57.6 \\
\hline $\begin{array}{c}\text { Adult and } \\
\text { General } \\
\text { Ward }\end{array}$ & Admission & 167,956 & 55,000 & -67.3 \\
\hline HIV clinic & Visit & 236,088 & 0 & -100.0 \\
\hline
\end{tabular}

Table 10 shows overall shows a very low cost recovery even when only the recurrent expenditures are considered. However, there is an increase in surplus under the OPD visit by about $1,300 \mathrm{Ugx}(0.5 \mathrm{USD})$, and a full cost recovery from laboratory.

\section{Discussion}

The results show an overall low cost recovery and this means without development partner support or the government the services under private not for profit may not be sustainable and this may also have an effect on quality of services provided. The high cost per major operation is basically because of the lower utilization of the services as outputs are a factor in the magnitude of an average cost.

\section{Recommendations}

1. Use of this information to justify need for more financing other than user fees to government and other development partners.

2. Adoption of a flat rate for all services in OPD as this will enhance certainty.

3. Since the theatre is underutilized the facility should consider revising the charges downwards and benefit from increased utilization and economies of scale and consider employing a surgeon.

4. Efficiency gain measures in terms of medicines selection and prescriptions should be implemented in attempt to reduce costs.

5. Government should increase support to the facility if it has to remain providing quality services at a low cost

\section{References}

[1] Adam et al., (2003), Econometric estimation of country's Specific hospital costs, cost effectiveness and Resource allocation 1:3; Oxford Press

[2] Ahairwe et al., (2003). Cost analysis of St. Marys Hospital Lacor 2001/2002. Uganda Martyrs University. Uganda Martyrs University Library.

[3] Batiringaya J., (2003), Study report on the effects of Abolition of cost sharing and its implications; Ministry of Health.

[4] Basaza R, Criel B and Van der Stuyft P, (2007).Low Enrollment in Ugandan Community Health Insurance Schemes: Underlying Causes and Policy Implications. BMC Health Services Research, 2007, 7: 105 doi: 10.1186/1472-6963-7-105 available from http://www.biomedcentral.com/1472-6963/7/105 (viewed 23 Nov 2013)

[5] Conteh L., Walker D., (2004). Cost and unit cost calculations using step-down accounting. Health Policy and Planning; 19(2): 127-135.

[6] Creese A., Parker D., (1994). Cost analysis in primary health care: a training manual for programme managers. Geneva: World Health Organisation.

[7] Flessa S., (1998). The cost of hospital services: A case study of Evangelical Lutheran Church hospitals in Tanzania. Health Policy and Planning; 13: 397-407

[8] Faculty of Health Sciences, Uganda Martyrs University, 2007: Cost Analysis of Services Provided at St. Francis Hospital Buluba in 2005/6 Financial Year (Unpublished)

[9] Faculty of Health Sciences, Uganda Martyrs University, 2007: Step-down Costing of Health Services of Kisubi Hospital for Financial Year 2005/6 (Unpublished)

[10]Flessa S, 1998: The Cost of Hospital Services: A Case Study of Evangelical Lutheran Church hospitals in Tanzania. Health Policy and Planning, 1998, 13(4): 397 $-407$

[11] Kadama P. (1990). A cost analysis study of two hospitals in Uganda. PhD Thesis. London School of Hygiene \& Tropical Medicine.

\section{Volume 5 Issue 6, June 2016 www.ijsr.net}




\section{International Journal of Science and Research (IJSR) \\ ISSN (Online): 2319-7064}

Index Copernicus Value (2013): 6.14 | Impact Factor (2015): 6.391

[12] Kyomuhangi LSB, 2005. Financial Implications of Scaling-up Antiretroviral Programs in Uganda and Senegal. Health Policy and Development, 3 (1) $12-20$.

[13]Lee K-H and Anderson YM, 2007: The Association between Clinical Pathways and Hospital Length of Stay: A Case Study. J Med Syst (2007) 31: $79-83$

[14] Murru M et al., 2004: Costing Health Services in Lacor Hospital, Health Policy and Development, 1 (1)

[15] Namaganda G, Kyobutungi N, Oketcho V, Matsiko C, Isabirye $\mathrm{C}$, Bamwonjobora $\mathrm{C}$, Abwaimo $\mathrm{F}$, Maniple $\mathrm{E}$, (2007): Introducing the Workload Indicator of Staffing Needs Methodology (WISN) in Uganda: A case study of Mukono and Mbale District Health Systems. (Unpublished)

[16] Okiria JC, Maniple E., Odaga J, Olaro C \& Namaganda G (2008). The Cost of Providing Specified Services Contained In the Benefit Package of the Proposed Social Health Insurance in Uganda $\mathrm{MOH}$

[17] Okiria J.C, Odaga J (2010) Cost effectiveness of CD4 Outreach model NUMAT USAID

[18] Shepard DS, Hodgkin D, Anthony Y. (1998). An Analysis of Hospital Costs: A Manual for Managers. Geneva: World Health Organization, Programme

Volume 5 Issue 6, June 2016 www.ijsr.net 